\title{
Platelets, Thrombocytosis, and Ovarian Cancer Prognosis: Surveying the Landscape of the Literature
}

\author{
Demetra H. Hufnagel ${ }^{1}$ (), Gabriella D. Cozzi ${ }^{1}$, Marta A. Crispens ${ }^{2,3}$ \\ and Alicia Beeghly-Fadiel ${ }^{3,4, *}$ \\ 1 Vanderbilt University School of Medicine, 2209 Garland Avenue, Nashville, TN 37240, USA; \\ demetra.h.hufnagel@vanderbilt.edu (D.H.H.); gabriellacozzi@uabmc.edu (G.D.C.) \\ 2 Department of Obstetrics and Gynecology, Division of Gynecologic Oncology, Vanderbilt University Medical \\ Center, 1161 21st Avenue South, Nashville, TN 37232, USA; marta.crispens@vumc.org \\ 3 Vanderbilt-Ingram Cancer Center, 1301 Medical Center Drive, Nashville, TN 37232, USA \\ 4 Department of Medicine, Division of Epidemiology, Vanderbilt University Medical Center, 2525 West End \\ Avenue, Nashville, TN 37203, USA \\ * Correspondence: alicia.beeghly@vumc.org
}

Received: 3 October 2020; Accepted: 27 October 2020; Published: 31 October 2020

\begin{abstract}
Platelets are critical components of a number of physiologic processes, including tissue remodeling after injury, wound healing, and maintenance of vascular integrity. Increasing evidence suggests that platelets may also play important roles in cancer. In ovarian cancer, thrombocytosis, both at the time of initial diagnosis and at recurrence, has been associated with poorer prognosis. This review describes current evidence for associations between thrombocytosis and ovarian cancer prognosis and discusses the clinical relevance of platelet count thresholds and timing of assessment. In addition, we discuss several mechanisms from in vitro, in vivo, and clinical studies that may underlie these associations and recommend potential approaches for novel therapeutic targets for this lethal disease.
\end{abstract}

Keywords: platelets; thrombocytosis; ovarian cancer; prognosis

\section{Introduction}

Circulating anucleate cytoplasmic fragments of megakaryocytes, platelets play critical and well-characterized roles in wound healing and maintenance of vascular integrity by adhering, activating, and aggregating at sites of vascular injury to form blood clots and stop bleeding [1]. While unprovoked thrombosis has long been associated with an increased risk of malignancy, as first described by Armand Trousseau in 1865, growing evidence has demonstrated an expanded role for platelets in the promotion of inflammation, tumorigenesis, and cancer metastasis [2-5]. Although platelets are anucleate, they have a number of cell surface receptors by which they interact with their environment, including integrins, selectins, immunoglobin receptors, and glycoproteins; they also contain a rich assortment of growth factors and mitogenic proteins in granules that they release following activation [1,6-9]. High platelet count, or thrombocytosis, is most often defined as $>400,000$ platelets per microliter and has been widely associated with poor cancer prognosis in a variety of solid tumors, including non-small cell lung cancer, advanced breast cancer, pancreatic cancer, colorectal cancer, and gastric cancer [10-18]. Although the mechanisms underlying associations between paraneoplastic thrombocytosis and cancer progression have yet to be fully elucidated, there is strong evidence for reciprocal interactions between tumor growth and platelet production and activation; accumulating data suggest that platelets are not only a biomarker of disease burden, with increased levels at diagnosis falling after primary treatment and again rising at recurrence, but also actively contribute to disease progression $[19,20]$. 
Ovarian cancer is the most lethal of the gynecologic cancers, with recent estimates of a relative 5 -year survival of $48 \%$, often due to diagnosis at late stage given non-specific symptoms and lack of sensitive population screening tools [21-24]. Although overall mortality from cancer has dramatically declined over recent decades, mortality from ovarian cancer has largely remained unchanged [21]. A better understanding of the pathogenesis of this disease is necessary for the development of additional therapeutic strategies. As with many other cancers, thrombocytosis is common during preoperative evaluation of women with epithelial ovarian cancer, affecting approximately $30 \%$ of patients [25]. Thrombocytosis has also been found to be associated with cancer risk in the setting of an adnexal mass, as well as characteristics of aggressive malignancy, including advanced stage, higher grade, larger volume of ascites, extensive residual disease following debulking, and chemoresistance [26-38]. A study of 30-day post-surgical outcomes among 1072 ovarian cancer cases demonstrated an association between thrombocytosis and major complications [39]. Moreover, thrombocytosis has been demonstrated to be a prognostic factor for multiple outcomes in numerous studies (Table 1) with significant associations from both univariate and multivariate analyses, suggesting independent associations with disease outcomes. The mechanisms behind these associations are now under investigation; therapeutics with anti-platelet activity, such as non-steroidal anti-inflammatory drugs (NSAIDs) including aspirin, have been associated with better prognosis in epidemiologic studies, and anti-platelet therapies are now being investigated in the ovarian cancer clinical setting [40-43].

Despite a large body of evidence supporting a role for thrombocytosis in ovarian cancer prognosis, clinical guidelines for monitoring platelets as a prognostic indicator to inform conversations with patients have yet to be determined. While prior meta-analyses and reviews have supported associations between pretreatment thrombocytosis and ovarian or gynecologic cancer survival, in this review we discuss timing of platelet count measurements and thresholds for thrombocytosis with regard to survival among women with epithelial ovarian cancer, with consideration of statistical adjustment and other important methodological differences $[44,45]$. We also describe a number of mechanisms potentially underlying these associations that suggest platelets are active contributors to the progression of disease and may present novel therapeutic targets in ovarian cancer. 
Table 1. Characteristics of Studies on Thrombocytosis and Ovarian Cancer Outcomes.

\begin{tabular}{|c|c|c|c|c|c|c|c|c|c|c|c|c|}
\hline \multirow{2}{*}{ Author } & \multirow{2}{*}{ Year } & \multicolumn{3}{|c|}{ Platelet Measurement Timeframe(s) } & \multirow{2}{*}{$\begin{array}{l}\text { Thrombocytosis } \\
\text { Threshold(s) }\end{array}$} & \multicolumn{3}{|c|}{ Study Population } & \multicolumn{2}{|c|}{ Statistical Analysis } & \multicolumn{2}{|c|}{ Prognostic Association(s) * } \\
\hline & & Description & Pretreatment & Additional & & Patients & Description & $\begin{array}{c}\begin{array}{c}\text { Source } \\
\text { (Country) }\end{array} \\
\end{array}$ & Outcome & Approach & PFS/DFS & OS/DSS \\
\hline Allensworth & 2013 & $\begin{array}{c}\text { Preoperative } \\
\text { (NOS) }\end{array}$ & Yes & & 450 & 578 & $\begin{array}{c}\text { epithelial } \\
\text { ovarian cancer }\end{array}$ & $\begin{array}{l}\text { United } \\
\text { States }\end{array}$ & DFS, OS & $\begin{array}{c}\text { KM, } \\
\text { PHreg }\end{array}$ & $\begin{array}{c}\text { Worse } \\
\text { (unadj, adj) }\end{array}$ & $\begin{array}{l}\text { Worse * } \\
\text { (unadj) }\end{array}$ \\
\hline Andersen & 2014 & $\begin{array}{l}\text { Up to 3-years } \\
\text { prior to diagnosis }\end{array}$ & Yes & & $\begin{array}{l}400 \text { (mild), } 550 \\
\quad \text { (severe) }\end{array}$ & 224 & $\begin{array}{l}\text { ovarian cancer } \\
\quad(\text { NOS })\end{array}$ & Denmark & $\begin{array}{c}\text { All-Cause and } \\
\text { Cancer-Specific } \\
\text { Mortality }\end{array}$ & $\begin{array}{l}\text { KM, } \\
\text { PHreg }\end{array}$ & \multicolumn{2}{|c|}{$\begin{array}{c}\text { Worse } \\
\text { (unadj, adj) }\end{array}$} \\
\hline Barber & 2015 & $\begin{array}{l}\text { Preoperative } \\
\text { (NOS) }\end{array}$ & Yes & & 450 & 1072 & $\begin{array}{l}\text { ovarian cancer } \\
\quad \text { (NOS) }\end{array}$ & $\begin{array}{l}\text { ACS } \\
\text { NSQIP } \\
\text { (US) }\end{array}$ & $\begin{array}{c}\text { 30-Day } \\
\text { Outcomes }\end{array}$ & $\begin{array}{l}\text { Logistic } \\
\text { Regression }\end{array}$ & \multicolumn{2}{|c|}{$\begin{array}{l}\text { Worse for major complications } \\
\quad \text { (unadj, adj) }\end{array}$} \\
\hline Bottsford-Miller & 2015 & $\begin{array}{l}\text { Pretreatment (at } \\
\text { diagnosis) and at } \\
\text { disease } \\
\text { recurrence }\end{array}$ & Yes & Yes & 450 & 341 & $\begin{array}{c}\text { recurrent } \\
\text { epithelial } \\
\text { ovarian cancer }\end{array}$ & $\begin{array}{l}\text { United } \\
\text { States }\end{array}$ & PFS, OS & KM & $\begin{array}{c}\mathrm{NS} \\
(\mathrm{P}=0.05)\end{array}$ & Worse \\
\hline Bozkurt & 2004 & $\begin{array}{l}\text { Second-look } \\
\text { laparotomy after } \\
\text { chemotherapy } \\
\text { (up to } 5 \text { days } \\
\text { prior) }\end{array}$ & & Yes & $\begin{array}{l}380 \text { (ROC), } \\
\text { continuous }\end{array}$ & 37 & $\begin{array}{c}\text { advanced stage } \\
\text { (III/IV) } \\
\text { epithelial } \\
\text { ovarian cancer }\end{array}$ & Turkey & $\begin{array}{l}\text { Presence of } \\
\text { Disease }\end{array}$ & $\begin{array}{l}\text { Wilcoxon } \\
\text { Signed } \\
\text { Rank Test }\end{array}$ & \multicolumn{2}{|c|}{$\begin{array}{c}\text { Worse } \\
(\mathrm{P}=0.025)\end{array}$} \\
\hline Canzler & 2020 & $\begin{array}{l}\text { Pretreatment for } \\
\text { recurrent disease }\end{array}$ & & Yes & 400 & 300 & $\begin{array}{c}\text { recurrent } \\
\text { epithelial } \\
\text { ovarian cancer }\end{array}$ & Germany & PFS, OS & $\begin{array}{l}\text { KM, } \\
\text { PHreg }\end{array}$ & $\begin{array}{c}\text { NS } \\
\text { (unadj) }\end{array}$ & $\begin{array}{l}\text { Worse* } \\
\text { (unadj) }\end{array}$ \\
\hline Chen, JP & 2019 & $\begin{array}{l}\text { Pretreatment } \\
\text { (NOS) }\end{array}$ & Yes & & 400 & 108 & $\begin{array}{l}\text { advanced stage } \\
\text { (IV) epithelial } \\
\text { ovarian cancer }\end{array}$ & China & PFS, OS & $\begin{array}{l}\text { KM, } \\
\text { PHreg }\end{array}$ & $\begin{array}{l}\text { NS (KM), } \\
\text { Worse in } \\
\text { combination } \\
\text { with CA-125 } \\
\text { (unadj, adj) }\end{array}$ & $\begin{array}{c}\text { Worse (KM), } \\
\text { Worse in } \\
\text { combination } \\
\text { with CA-125 } \\
\text { (unadj, adj) }\end{array}$ \\
\hline Chen, Y & 2015 & $\begin{array}{l}\text { Pretreatment } \\
\text { (NOS) }\end{array}$ & Yes & & 400 & 816 & $\begin{array}{c}\text { epithelial } \\
\text { ovarian cancer }\end{array}$ & China & PFS, OS & $\begin{array}{l}\text { KM, } \\
\text { PHreg }\end{array}$ & $\begin{array}{l}\text { Worse } \\
\text { (unadj, adj) }\end{array}$ & $\begin{array}{l}\text { Worse } \\
\text { (unadj, adj) }\end{array}$ \\
\hline Cohen & 2014 & $\begin{array}{l}\text { Cytoreductive } \\
\text { surgery for } \\
\text { recurrent disease }\end{array}$ & & Yes & 350 & 107 & $\begin{array}{c}\text { recurrent } \\
\text { epithelial } \\
\text { ovarian cancer }\end{array}$ & $\begin{array}{l}\text { United } \\
\text { States }\end{array}$ & Os & $\begin{array}{l}\text { KM, } \\
\text { PHreg }\end{array}$ & & $\begin{array}{c}\text { Worse } \\
\text { (unadj, adj) }\end{array}$ \\
\hline Cozzi & 2016 & $\begin{array}{l}\text { Date of diagnosis } \\
\text { and up to } 1,2,4, \\
\text { and } 8 \text { weeks prior }\end{array}$ & Yes & & $350,400,450$ & 304 & $\begin{array}{c}\text { epithelial } \\
\text { ovarian cancer }\end{array}$ & $\begin{array}{l}\text { United } \\
\text { States }\end{array}$ & OS & $\begin{array}{l}\text { KM, } \\
\text { PHreg }\end{array}$ & & $\begin{array}{c}\text { Worse } \\
\text { (unadj, adj) }\end{array}$ \\
\hline Digklia & 2014 & $\begin{array}{l}\text { Pretreatment } \\
\text { (at diagnosis) }\end{array}$ & Yes & & 350 & 91 & $\begin{array}{c}\text { stage III/IV } \\
\text { serous ovarian } \\
\text { cancer }\end{array}$ & Switzerland & PFS, OS & $\begin{array}{l}\text { KM, } \\
\text { PHreg }\end{array}$ & $\begin{array}{c}\text { Worse } \\
\text { (unadj, adj) }\end{array}$ & $\begin{array}{c}\text { Worse } \\
\text { (unadj, adj) }\end{array}$ \\
\hline
\end{tabular}


Table 1. Cont.

\begin{tabular}{|c|c|c|c|c|c|c|c|c|c|c|c|c|}
\hline \multirow{2}{*}{ Author } & \multirow{2}{*}{ Year } & \multicolumn{3}{|c|}{ Platelet Measurement Timeframe(s) } & \multirow{2}{*}{$\begin{array}{l}\text { Thrombocytosis } \\
\text { Threshold(s) }\end{array}$} & \multicolumn{3}{|c|}{ Study Population } & \multicolumn{2}{|c|}{ Statistical Analysis } & \multicolumn{2}{|c|}{ Prognostic Association(s) * } \\
\hline & & Description & Pretreatment & Additional & & Patients & Description & $\begin{array}{c}\begin{array}{c}\text { Source } \\
\text { (Country) }\end{array} \\
\end{array}$ & Outcome & Approach & PFS/DFS & OS/DSS \\
\hline Eggemann & 2015 & $\begin{array}{c}\text { At diagnosis, } \\
\text { after surgery, } \\
\text { before and after } \\
\text { chemotherapy, } \\
\text { and disease } \\
\text { recurrence }\end{array}$ & Yes & Yes & 350 & 132 & $\begin{array}{l}\text { ovarian cancer } \\
\text { (NOS) }\end{array}$ & Germany & PFS, OS & $\begin{array}{l}\text { KM, } \\
\text { PHreg }\end{array}$ & $\begin{array}{l}\text { Worse for } \\
\quad<25 \% \\
\text { reduction } \\
\text { (unadj, adj) }\end{array}$ & $\begin{array}{l}\text { Worse for } \\
\quad<25 \% \\
\text { reduction } \\
\text { (unadj, adj) }\end{array}$ \\
\hline Feng & 2016 & $\begin{array}{c}\text { Preoperative } \\
\text { (NOS) }\end{array}$ & Yes & & 450 & 874 & $\begin{array}{l}\text { high-grade } \\
\text { serous ovarian } \\
\text { cancer }\end{array}$ & China & PFS, OS & KM & NS & NS \\
\hline Gerestein & 2009 & $\begin{array}{l}\text { Preoperative } \\
\text { (within } 1 \text { week of } \\
\text { surgery) }\end{array}$ & Yes & & continuous & 118 & $\begin{array}{l}\text { advanced stage } \\
\text { (IIB-IV) } \\
\text { epithelial } \\
\text { ovarian cancer }\end{array}$ & $\begin{array}{l}\text { The } \\
\text { Netherlands }\end{array}$ & PFS, OS & $\begin{array}{l}\text { KM, } \\
\text { PHreg }\end{array}$ & $\begin{array}{c}\text { Worse } \\
\text { (unadj, adj) }\end{array}$ & $\begin{array}{c}\text { Worse } \\
\text { (unadj, adj) }\end{array}$ \\
\hline Gungor & 2009 & $\begin{array}{c}\text { Preoperative } \\
\text { (within } 14 \text { days of } \\
\text { surgery) }\end{array}$ & Yes & & 400 & 292 & $\begin{array}{c}\text { epithelial } \\
\text { ovarian cancer }\end{array}$ & Turkey & OS & $\begin{array}{l}\text { KM, } \\
\text { PHreg }\end{array}$ & & $\begin{array}{c}\text { Worse } \\
\text { (unadj, adj) }\end{array}$ \\
\hline $\begin{array}{l}\text { Hefler- } \\
\text { Frischmuth }\end{array}$ & 2018 & $\begin{array}{l}\text { Preoperative } \\
\text { (24-72 } \mathrm{h} \text { prior to } \\
\text { initial surgery) }\end{array}$ & Yes & & 450 , continuous & 498 & $\begin{array}{c}\text { epithelial } \\
\text { ovarian cancer }\end{array}$ & Austria & OS & $\begin{array}{l}\text { KM, } \\
\text { PHreg }\end{array}$ & & $\begin{array}{l}\text { Worse* } \\
\text { (unadj) }\end{array}$ \\
\hline $\mathrm{Hu}$ & 2020 & $\begin{array}{l}\text { Pretreatment, } \\
14 \text { days after } \\
\text { chemotherapy, } \\
\text { and disease } \\
\text { recurrence }\end{array}$ & Yes & Yes & 300 & 104 & $\begin{array}{c}\text { recurrent } \\
\text { epithelial } \\
\text { ovarian cancer }\end{array}$ & China & PFS, OS & $\begin{array}{c}\text { KM, } \\
\text { PHreg }\end{array}$ & $\begin{array}{c}\text { Worse } \\
\text { (unadj, adj) }\end{array}$ & $\begin{array}{c}\text { Worse } \\
\text { (unadj, adj) }\end{array}$ \\
\hline Komura & 2019 & $\begin{array}{l}\text { Lowest measure } \\
\text { between } \\
\text { diagnosis and } \\
\text { treatment }\end{array}$ & Yes & & 427 (ROC) & 308 & $\begin{array}{c}\text { epithelial } \\
\text { ovarian cancer }\end{array}$ & Japan & DSS & $\begin{array}{c}\text { KM, } \\
\text { PHreg }\end{array}$ & & $\begin{array}{c}\text { Worse } \\
\text { (unadj, adj) }\end{array}$ \\
\hline Lee & 2011 & $\begin{array}{l}\text { Preoperative } \\
\text { (within } 7 \text { days } \\
\text { prior to surgery) } \\
\text { and after } \\
\text { adjuvant } \\
\text { chemotherapy }\end{array}$ & Yes & Yes & 400 & 179 & $\begin{array}{c}\text { advanced stage } \\
\text { (III/IV) } \\
\text { epithelial } \\
\text { ovarian cancer }\end{array}$ & Korea & PFS, OS & $\begin{array}{c}\text { KM, } \\
\text { PHreg }\end{array}$ & $\begin{array}{c}\text { NS } \\
\text { (unadj) }\end{array}$ & $\begin{array}{c}\text { Worse } \\
\text { (unadj, adj) }\end{array}$ \\
\hline $\mathrm{Li}$ & 2004 & $\begin{array}{c}\text { Preoperative } \\
\text { (within } 14 \text { days of } \\
\text { surgery) }\end{array}$ & Yes & & 400 & 144 & $\begin{array}{c}\text { advanced stage } \\
\text { (III/IV) } \\
\text { epithelial } \\
\text { ovarian cancer }\end{array}$ & $\begin{array}{l}\text { United } \\
\text { States }\end{array}$ & DFS, OS & $\begin{array}{c}\text { KM, } \\
\text { PHreg }\end{array}$ & $\begin{array}{c}\text { Worse } \\
\text { (unadj, adj) }\end{array}$ & $\begin{array}{c}\text { Worse } \\
\text { (unadj, adj) }\end{array}$ \\
\hline Ma & 2013 & $\begin{array}{l}\text { Preoperative } \\
\text { (within } 7 \text { days } \\
\text { prior to surgery) }\end{array}$ & Yes & & 400 & 182 & $\begin{array}{c}\text { epithelial } \\
\text { ovarian cancer }\end{array}$ & China & PFS, OS & $\begin{array}{l}\text { KM, } \\
\text { PHreg }\end{array}$ & $\begin{array}{c}\text { Worse in } \\
\text { combination } \\
\text { with MAR } \\
\text { (unadj, adj) }\end{array}$ & $\begin{array}{c}\text { Worse in } \\
\text { combination } \\
\text { with MAR } \\
\text { (unadj, adj) }\end{array}$ \\
\hline
\end{tabular}


Table 1. Cont

\begin{tabular}{|c|c|c|c|c|c|c|c|c|c|c|c|c|}
\hline \multirow{2}{*}{ Author } & \multirow{2}{*}{ Year } & \multicolumn{3}{|c|}{ Platelet Measurement Timeframe(s) } & \multirow{2}{*}{$\begin{array}{l}\text { Thrombocytosis } \\
\text { Threshold(s) }\end{array}$} & \multicolumn{3}{|c|}{ Study Population } & \multicolumn{2}{|c|}{ Statistical Analysis } & \multicolumn{2}{|c|}{ Prognostic Association(s) * } \\
\hline & & Description & Pretreatment & Additional & & Patients & Description & $\begin{array}{c}\text { Source } \\
\text { (Country) }\end{array}$ & Outcome & Approach & PFS/DFS & OS/DSS \\
\hline Man & 2015 & $\begin{array}{l}\text { Pretreatment (up } \\
\text { to } 7 \text { days prior) }\end{array}$ & Yes & & 300 & 190 & $\begin{array}{c}\text { epithelial } \\
\text { ovarian cancer }\end{array}$ & China & $\begin{array}{l}\text { PFS, OS } \\
\text { (3-year) }\end{array}$ & $\begin{array}{c}\text { KM, } \\
\text { PHreg }\end{array}$ & $\begin{array}{c}\text { Worse } \\
\text { (unadj, adj) }\end{array}$ & $\begin{array}{c}\text { Worse } \\
\text { (unadj, adj) }\end{array}$ \\
\hline Matsuo & 2015 & $\begin{array}{l}\text { At diagnosis and } \\
\text { at disease } \\
\text { progression or } \\
\text { recurrence }\end{array}$ & Yes & Yes & 400 & 1308 & $\begin{array}{l}\text { clear cell and } \\
\text { serous ovarian } \\
\text { cancer }\end{array}$ & $\begin{array}{c}10 \\
\text { academic } \\
\text { institutions } \\
\text { (US, } \\
\text { Japan, } \\
\text { England) }\end{array}$ & PFS, OS & $\begin{array}{l}\text { KM, } \\
\text { PHreg }\end{array}$ & $\begin{array}{c}\text { Worse } \\
\text { (unadj, adj) }\end{array}$ & $\begin{array}{c}\text { Worse } \\
\text { (unadj, adj) }\end{array}$ \\
\hline Menczer & 1998 & $\begin{array}{l}\text { Preoperative } \\
\text { (NOS) }\end{array}$ & Yes & & 400 & 70 & $\begin{array}{c}\text { epithelial } \\
\text { ovarian cancer }\end{array}$ & Israel & OS & KM & & Worse \\
\hline Nakao & 2020 & $\begin{array}{l}\text { Pretreatment } \\
\text { (mean of initial } \\
\text { and } \\
\text { pre-treatment } \\
\text { evaluations) }\end{array}$ & Yes & & 400 & 280 & $\begin{array}{c}\text { epithelial } \\
\text { ovarian cancer }\end{array}$ & Japan & PFS, OS & $\begin{array}{l}\text { KM, } \\
\text { PHreg }\end{array}$ & $\begin{array}{c}\text { Worse } \\
\text { (unadj, adj) }\end{array}$ & $\begin{array}{c}\text { Worse } \\
\text { (unadj, adj) }\end{array}$ \\
\hline Okunade & 2020 & $\begin{array}{l}\text { Pretreatment (at } \\
\text { diagnosis) }\end{array}$ & Yes & & 450 & 72 & $\begin{array}{c}\text { epithelial } \\
\text { ovarian cancer }\end{array}$ & Nigeria & $\begin{array}{l}\text { PFS, OS } \\
\text { (3-year) }\end{array}$ & $\begin{array}{c}\text { KM, } \\
\text { PHreg }\end{array}$ & $\begin{array}{c}\text { Worse } \\
\text { (unadj, adj) }\end{array}$ & $\begin{array}{c}\text { Worse } \\
\text { (unadj, adj) }\end{array}$ \\
\hline Qiu & 2012 & $\begin{array}{l}\text { Preoperative } \\
\text { (2-4 days prior) }\end{array}$ & Yes & & 400 & 136 & $\begin{array}{l}\text { epithelial } \\
\text { ovarian cancer }\end{array}$ & China & PFS, OS & $\begin{array}{c}\text { KM, } \\
\text { PHreg }\end{array}$ & $\begin{array}{l}\text { Worse * } \\
\text { (unadj) }\end{array}$ & $\begin{array}{l}\text { Worse * } \\
\text { (unadj) }\end{array}$ \\
\hline $\begin{array}{l}\text { Słabuszewska- } \\
\text { Jóźwiak }\end{array}$ & 2015 & $\begin{array}{c}\text { Preoperative (1 } \\
\text { day before } \\
\text { surgery) }\end{array}$ & Yes & & 350 & 97 & $\begin{array}{l}\text { ovarian cancer } \\
\text { (not all } \\
\text { epithelial) }\end{array}$ & Poland & DFS, OS & $\begin{array}{l}\text { Mann-Whitney } \\
\text { U Test }\end{array}$ & NS & Worse \\
\hline Soonthornthum & 2007 & $\begin{array}{c}\text { Preoperative } \\
\text { (within } 14 \text { days of } \\
\text { surgery) }\end{array}$ & Yes & & 305 (ROC), 400 & 74 & $\begin{array}{c}\text { epithelial } \\
\text { ovarian cancer }\end{array}$ & Thailand & OS & KM & & Worse \\
\hline Stone & 2012 & $\begin{array}{l}\text { Preoperative } \\
\text { (NOS) }\end{array}$ & Yes & & 450 & 619 & $\begin{array}{c}\text { epithelial } \\
\text { ovarian cancer }\end{array}$ & $\begin{array}{l}\text { United } \\
\text { States }\end{array}$ & PFS, OS & $\begin{array}{c}\text { KM, } \\
\text { PHreg }\end{array}$ & $\begin{array}{l}\text { Worse } \\
\text { (unadj) }\end{array}$ & $\begin{array}{c}\text { Worse } \\
\text { (unadj, adj) }\end{array}$ \\
\hline Tang & 2017 & $\begin{array}{l}\text { Preoperative } \\
\text { (NOS) }\end{array}$ & Yes & & $\begin{array}{c}300,327 \text { (ROC), } 350 \\
400\end{array}$ & 171 & $\begin{array}{c}\text { epithelial } \\
\text { ovarian cancer }\end{array}$ & China & Os & KM & & Worse \\
\hline Zeimet & 1994 & $\begin{array}{l}\text { Preoperative } \\
\text { (NOS) }\end{array}$ & Yes & & 400 & 130 & $\begin{array}{c}\text { epithelial } \\
\text { ovarian cancer }\end{array}$ & Austria & OS (4-year) & KM & & NS \\
\hline
\end{tabular}

Abbreviations: adj—adjusted; DFS—disease-free survival; DSS—disease-specific survival; KM—Kaplan-Meier analysis; MAR—Mean Aggregation Rate; NOS—not otherwise specified; NS—not significant; OS—overall survival; P— $p$-value; PFS—-progression-free survival; PHreg—proportional hazards regression; ROC—receiver operating curve; unadj—unadjusted;

US-United States. * Denotes that adjusted proportional hazards regression model was not significant. 


\section{Pretreatment Thrombocytosis and Associations with Survival}

To the best of our knowledge, 29 studies have evaluated the prognostic utility of thrombocytosis for ovarian cancer in the preoperative setting-either at primary staging and/or cytoreduction—or pretreatment. We focus primarily on 27 that conducted Kaplan-Meier and/or Cox proportional hazards regression to estimate associations with progression-free survival (PFS), disease-free survival (DFS), disease-specific survival (DSS), and/or overall survival (OS). To facilitate review of studies with varied methodologies, we have presented the relevant literature divided by thrombocytosis threshold (below 400,400 , above 400 , and multiple thresholds or continuous measures), with the timeframe within which platelet counts were included also being considered.

\subsection{Pretreatment Thrombocytosis and Associations with Survival: Timing of Platelet Count Measurement}

Among 27 studies that have assessed thrombocytosis prior to treatment in relation to ovarian cancer survival, only $12(44 \%)$ provide the specific time frame within which platelet counts were included; these have ranged from the date of diagnosis to up to 8 weeks or 3 years prior to diagnosis $[26,46]$. Many studies have used a time frame of within 7 or 14 days of initial staging and/or cytoreductive surgery, but whether the date of diagnosis was included has been rarely stated. The remaining studies have examined platelet counts from either the "preoperative" or "pretreatment" setting without any further specification.

\subsection{Pretreatment Thrombocytosis and Associations with Survival: Thresholds Below 400}

Several small studies employing a threshold below $400 \times 10^{9} / \mathrm{L}$ for thrombocytosis in relation to ovarian cancer prognosis have had significant findings. In a small study of 97 patients in Poland with platelet counts measured 1 day prior to staging and/or debulking surgery, thrombocytosis $(\geq 350)$ was found to be a negative prognostic factor for OS, although no regression was conducted [47]. In a study of 91 advanced stage serous cases in Switzerland, thrombocytosis (>350) was an independent negative prognostic factor for two-fold worse PFS and OS, even after multivariable regression including adjustment for age, stage, menopausal status, CA-125, and optimal tumor debulking [27]. In a study with 104 patients in China with recurrent disease, pre-primary treatment thrombocytosis $(\geq 300)$ conferred significantly worse PFS and OS, even when regression models included adjustment for age, stage, grade, residual disease after cytoreduction, and reduced platelet count after completion of first-line treatment [48]. Similarly, in a study of 190 patients in China with platelet measurements up to 7 days prior to treatment, thrombocytosis ( $>300$ ) was significantly associated with approximately $50 \%$ worse 3-year PFS and OS in models that included adjustment for age, stage, grade, optimal debulking, timing of surgery, chemotherapy, clotting factors, and thrombotic events [32].

\subsection{Pretreatment Thrombocytosis and Associations with Survival: Thresholds of 400}

Multiple studies have employed a threshold of $400 \times 10^{9} / \mathrm{L}$ for thrombocytosis in relation to ovarian cancer prognosis, with most reporting significant findings. An early study of 70 patients in Israel found that those with thrombocytosis had worse OS [49], while a study of 130 patients in Austria found no difference, although their mean follow-up was only two years [50]. Among 136 cases from China, initially significant associations with PFS and OS were attenuated after regression models included adjustment for stage, cytoreduction, chemotherapy, CA-125, and plasma fibrinogen level, which was significantly correlated with platelet count $(r=0.45)$ [51]. In a United States (U.S.) study with platelet measurements from up to 14 days prior to diagnosis, thrombocytosis was significantly associated with two-fold worse OS when multivariable regression models were limited to 144 patients with late stage (III and IVA) disease [30]. Similarly, in a study of 179 women in Korea with advanced stage (III and IV) disease, thrombocytosis based on measurements from up to 7 days prior to diagnosis was associated with approximately three-fold worse OS, even after adjustment for tumor histology, platelet count following chemotherapy, and CA-125 following primary chemotherapy [33]. Among 280 
ovarian cancer cases in Japan, associations with PFS and OS were significant in both unadjusted and multivariable adjusted regression models [52], and among 292 cases in Turkey, OS was two-fold worse for those with thrombocytosis based on measurements from within 14 days of surgery [53]. In a large study of 816 patients in China, thrombocytosis was associated with significantly increased hazards of disease progression and death, even when multivariable regression models included adjustment for age, stage, grade, ascites, optimal debulking, and anemia [54]. The largest study to date included 1308 cases with clear cell or serous ovarian cancer from 10 academic institutions; thrombocytosis was an independent predictor of both PFS and OS, even in regression models that included adjustment for venous thromboembolism (VTE) [55]. In addition, two studies have assessed thrombocytosis in relation to ovarian cancer survival in combination with other factors. Among 108 advanced stage (IV) patients in China, those with thrombocytosis and/or elevated CA-125 had significantly worse PFS and OS [56], while among 182 patients in China, those with thrombocytosis and a high platelet mean aggregation rate (MAR) had more than three-fold higher hazards of death [31].

\subsection{Pretreatment Thrombocytosis and Associations with Survival: Thresholds Above 400}

Multiple studies have employed a threshold of $450 \times 10^{9} / \mathrm{L}$ for pretreatment thrombocytosis, but in studies that have used only this threshold, specific timings of platelet measurements have not been described and findings have been mixed. In a small study of 72 ovarian cancer cases in Nigeria, thrombocytosis was significantly associated with worse PFS and OS within 3 years [57]. A multi-institution study that included 341 patients with recurrent or progressive disease reported that thrombocytosis at diagnosis was a negative prognostic factor for both PFS and OS, although proportional hazards regression was not conducted [34]. Some of these patients were also included in a larger study of 619 total patients from four academic medical centers in the U.S. where thrombocytosis was found to be an independent predictor of survival, with $80 \%$ worse OS, even after statistical adjustment for age, stage, grade, histologic subtype, and cytoreduction [25]. This finding was replicated among 578 cases from the Mayo Clinic, where thrombocytosis was associated with approximately $40 \%$ worse DFS and OS, although significance was attenuated when Eastern Cooperative Oncology Group (ECOG) performance status and American Society of Anesthesiologists (ASA) scores were included in the regression models [29]. Among 874 high-grade serous ovarian cancer cases in China, thrombocytosis was significantly associated with stage, ascites volume, residual disease after debulking, and chemosensitivity, but not PFS or OS in Kaplan-Meier survival analysis [28]. However, hyperfibrinogenemia $(>4 \mathrm{~g} / \mathrm{L})$ was significantly associated with survival, leading the authors to conclude that while thrombocytosis reflects tumor burden and thus influences treatment outcomes, only fibrinogen was a useful prognostic factor for high-grade serous ovarian cancer [28].

\subsection{Pretreatment Thrombocytosis and Associations with Survival: Multiple Thresholds and Continuous Measures}

Studies that have compared multiple thresholds for thrombocytosis or evaluated continuous measures of platelet counts in the context of ovarian cancer survival are less common. One study with 120 cases from Thailand started with an a priori threshold of 400, but then conducted a Receiver Operating Curve (ROC) analysis on the relationship between thrombocytosis and stage, finding that 305 was best able to differentiate between early and advanced disease [58]. When both thresholds (305, 400 ) were evaluated with regard to survival in a cohort of 74 patients with advanced epithelial ovarian cancer, only platelet counts above the 305 threshold from up to 14 days before primary surgery were significantly associated with worse overall survival in Kaplan-Meier analysis, but no proportional hazards regression was conducted [58]. A study of 308 patients in Japan used ROC analysis to define an optimal threshold for preoperative thrombocytosis and disease-specific survival; if the lowest platelet count between diagnosis and treatment was above $427 \times 10^{9} / \mathrm{L}$, then patients had a nearly two-fold increased risk of death due to ovarian cancer, even following adjustment for known clinical covariates, such as age, stage, metastasis, and cytoreduction [59]. However, this association was attenuated when 
the analysis was stratified by nutritional status, based on serum albumin and lymphocyte count, which was inversely correlated with platelet count $(r=-0.39)$ [59]. A cohort study in Denmark with 224 women who developed ovarian cancer used platelet counts from up to 3 years before diagnosis and defined thrombocytosis as mild $\left(>400 \times 10^{9} / \mathrm{L}\right)$ or severe $\left(>550 \times 10^{9} / \mathrm{L}\right)$; while mild was not significantly associated, severe thrombocytosis conferred a more than two-fold increased risk of cancer-specific and overall mortality [46]. Our prior study of 304 cases from the Vanderbilt University Medical Center (VUMC) compared three thresholds (350,400, and 450), with increasing timeframes (on the date of, and 1, 2, 4, and 8 weeks prior to diagnosis); with the exception of the lowest threshold on the date of diagnosis, all other associations were significant, with estimates ranging from $50 \%$ to a two-fold increased risk of death [26]. A smaller study of 171 ovarian cancer cases from China supported these findings, comparing thresholds of 300, 350, and 400 in Kaplan-Meier analysis; all three thresholds were associated with worse OS, and ROC analysis suggested an optimal threshold of $>327.5 \times 10^{9} / \mathrm{L}$ for predicting overall survival [60]. A larger study of 498 patients in Austria evaluated thrombocytosis using both $\mathrm{a} \geq 450 \times 10^{9} / \mathrm{L}$ threshold and a continuous measure; although initially significant, neither remained associated with OS after statistical adjustment for age, stage, grade, histologic subtype, residual disease, and serum sodium measures [61]. Finally, among 118 advanced stage cases from the Netherlands, each unit increase in platelet count within a week prior to surgery conferred a $0.2 \%$ increased risk of disease progression or death [62].

\subsection{Pretreatment Thrombocytosis and Associations with Survival: Multivariable Adjustment}

The relationship between pretreatment thrombocytosis and ovarian cancer survival seems to be robust, as regression models from studies where significance was not attenuated have adjusted for a multitude of clinical covariates, including age, stage, grade, histologic subtype, chemotherapy, chemosensitivity, optimal tumor debulking/residual disease after cytoreduction, ascites volume, CA-125, menopausal status, anemia, and thrombotic events/VTE [25-27,30,32,33,48,52-55,57,59,62]. However, multivariable adjustment has resulted in attenuation of the association between thrombocytosis and ovarian cancer survival in some cases, such as when adjustment included plasma fibrinogen level, serum sodium measures, or ECOG and ASA scores [29,51,61]. Attenuation of an association after multivariable adjustment may indicate a false negative finding, possibly due to highly collinear variables being included in a regression model, or an inadequate sample size. Alternatively, thrombocytosis may not be an independent prognostic factor for ovarian cancer, although so many studies reporting an independent association due to chance (i.e., false positive findings) is unlikely.

\section{Thrombocytosis after Primary Treatment and Associations with Survival}

Eight studies have evaluated the prognostic utility of thrombocytosis for ovarian cancer in the post-diagnostic period, most frequently focused on platelet count at the time of disease progression or recurrence. Timeframes ranged from before or after first-line chemotherapy to preoperative platelet counts for second-look laparotomy or secondary cytoreductive surgery for recurrent disease. Similar to pretreatment criteria, thrombocytosis thresholds ranged from 300 to $450 \times 10^{9} / \mathrm{L}$.

\subsection{Thrombocytosis Following Chemotherapy and Associations with Survival}

Three studies on thrombocytosis in ovarian cancer have included chemotherapy-related platelet counts. A study in China of 104 patients with recurrent disease evaluated not only pretreatment measures, but also those taken 14 days after completing chemotherapy and at the time of disease recurrence; in line with prior studies, they found that platelet levels generally declined at the end of primary therapy and rose again at disease recurrence $[20,48]$. The ratio between pretreatment and post-chemotherapy platelet counts was calculated, and a reduction of less than $25 \%$ was found to be an independent negative prognostic factor for survival with a greater than 2-fold increased risk of death even when pretreatment platelet count was adjusted for [48]. A study with 132 ovarian cancer patients in Germany evaluated platelet counts at diagnosis, after surgery, before and after chemotherapy, and at 
the time of recurrence if applicable; when the ratio of platelet counts before and after chemotherapy was assessed, a less than $25 \%$ reduction was found to be an independent negative prognostic factor for both PFS and OS [20]. Among 179 advanced stage (III and IV) cases in Korea, thrombocytosis ( $\geq 400 \times$ $10^{9}$ platelets/L) after primary adjuvant chemotherapy was associated with significantly worse OS [33].

\subsection{Thrombocytosis at Disease Recurrence and Associations with Survival}

Three studies on thrombocytosis in ovarian cancer have examined platelet counts around the time of recurrence in relation to prognosis. A study of 107 patients in the U.S. demonstrated that preoperative thrombocytosis $\left(\geq 350 \times 10^{9}\right.$ platelets/L) at the time of secondary cytoreductive surgery was significantly associated with suboptimal resection and worse OS in both unadjusted and adjusted analyses [63]. A study of 300 cases with recurrent disease who participated in three phase-III clinical trials (AGO-OVAR 2.2, AGO-OVAR 2.3, and AGO-OVAR 2.9) found that thrombocytosis $\left(\geq 400 \times 10^{9}\right.$ platelets/L) prior to second-line chemotherapy was associated with chemoresistance and worse OS; however, when regression models included ECOG performance status, significance of the association was attenuated [64]. Notably, this study excluded cases who underwent secondary cytoreductive surgery before randomization to trial, as thrombocytosis may be associated with acute inflammation and stress-response following surgical procedures. A study of 787 women with clear cell or serous ovarian cancer from ten academic institutions in England, Japan, and the U.S., found that thrombocytosis ( $\geq 400$ $\times 10^{9}$ platelets/L) at disease recurrence or progression was an independent predictor for $60 \%$ decreased two-year OS, even after age, CA-125, histologic subtype, and VTE were adjusted for [55].

Although time-to-event analyses were not conducted, two additional studies have evaluated post-diagnosis platelet counts. A small prospective study used ROC analysis to identify an optimal threshold of $380 \times 10^{9} / \mathrm{L}$ to differentiate between patients with and without disease recurrence or progressive disease at the time of second-look laparotomy; among 37 patients, those with higher platelet counts after completing chemotherapy were also more likely to have evidence of disease progression at the time of second-look surgery [65]. Similarly, a retrospective study identified 96 cases from three academic medical centers in the U.S. with platelet data spanning initial diagnosis, primary treatment, and diagnosis of disease recurrence; counts were found to decrease during primary therapy and again increase at disease recurrence [34]. Further, among a subset of 20 cases matched on clinical covariates, ten with a durable response were more likely than ten with treatment refractory disease to have a normalized platelet count at the end of primary chemotherapy [34].

\section{Mechanisms Underlying Associations of Thrombocytosis with Disease Progression}

While a large body of epidemiologic literature suggests that platelets are associated with ovarian cancer prognosis, mechanistic studies evaluating the role of platelets in modulating disease progression provide evidence that this association is not purely correlative; both preclinical and clinical studies demonstrate that platelets and cancer cells influence each other in a bidirectional manner, wherein malignant neoplasms support thrombocytosis and increased platelets drive tumorigenesis and metastasis (Figure 1) [3]. 


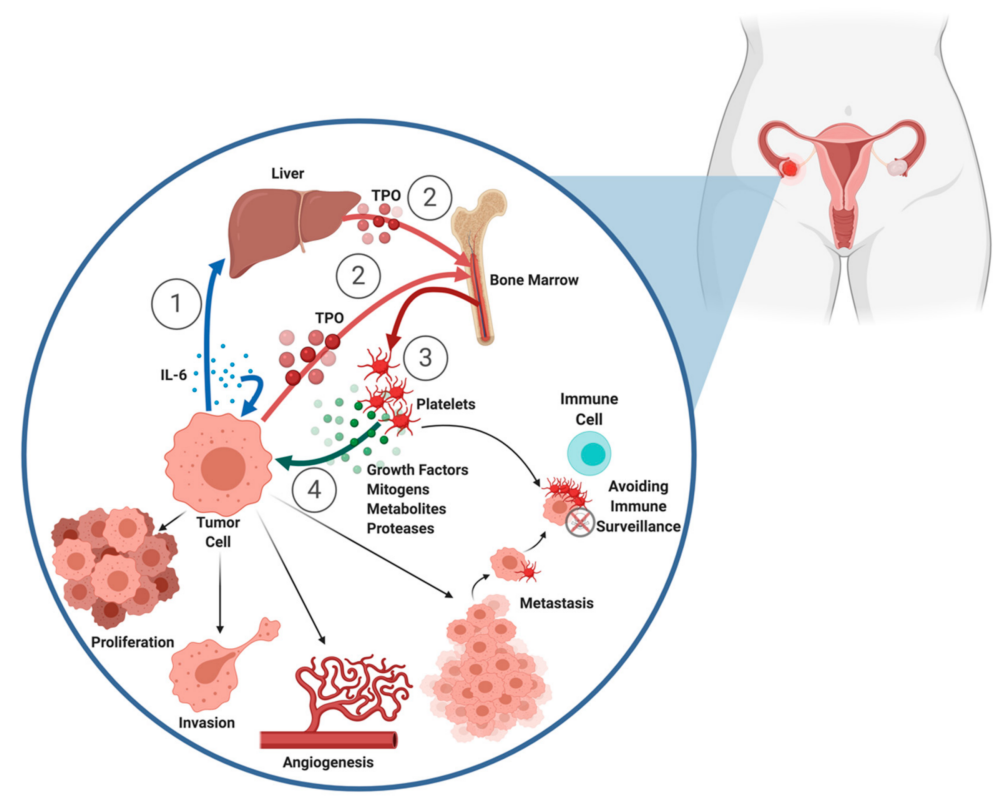

Figure 1. Contributions of platelets to ovarian cancer progression. (1) Tumor cells produce the cytokine interleukin-6 (IL-6). (2) IL-6 drives production of thrombopoietin (TPO) directly from tumor cells as well as the liver. (3) TPO stimulates production and release of platelets from bone marrow. (4) Platelets support cancer cell proliferation, invasion, angiogenesis, migration, and metastasis through release of growth factors, mitogens, metabolites, and proteases. They may also act as sites of seeding for metastasis and form aggregates with tumor cells to shield them from immune surveillance. Figure 1 is an original figure that was created by the authors using BioRender.com.

\subsection{Cytokine-Driven Development of Thrombocytosis in Ovarian Cancer}

Prior studies have established that paraneoplastic thrombocytosis is driven in part by cancer cell-mediated release of interleukin-6 (IL-6), which stimulates the production of hepatic-derived and/or cancer-cell derived thrombopoietin to drive platelet overproduction $[25,66,67]$. In orthotopic and syngeneic murine models of ovarian cancer, increases in disease burden are associated with concomitant increases in IL-6 and platelet counts [25]. Critically, in these studies, blockage of IL-6 rescued mice from cancer-associated thrombocytosis, and murine models lacking a hepatic IL-6 receptor did not have elevations in platelet count associated with tumor growth, corroborating the major role IL-6 plays in mediating cancer-related thrombocytosis. In human samples, ovarian tumor and plasma expression of IL-6 was likewise significantly associated with plasma thrombopoietin levels as well as thrombocytosis. There is some evidence that in cancers with PIK3CA mutations, such as endometrioid and clear cell ovarian cancers, upregulation of nuclear factor-kappaB (NF- $\mathrm{KB}$ ) pathways may drive the expression of IL-6, perhaps relating known associations between increased NF- $\mathrm{kB}$ expression and poor prognosis in ovarian cancer to mechanisms underlying associations with thrombocytosis [68-74].

\subsection{Contributions of Platelets to Ovarian Cancer Progression: In Vitro and In Vivo Studies}

A number of in vitro and in vivo studies have demonstrated that exposure to platelets drives anti-apoptotic, pro-invasive, and pro-angiogenic activity in human ovarian cancer cells. This is perhaps unsurprising given that platelets contain a variety of growth factors, mitogens, metabolites, and proteases in their granules and lysosomes, including platelet-derived growth factor (PDGF), transforming growth factor (TGF), vascular endothelial growth factor (VEGF), metalloproteinases, collagenases, and elastases [1,7-9].

Platelets may stimulate cells within the tumor microenvironment, either directly or indirectly through paracrine mechanisms, driving further production of pro-tumorigenic products and phenotypic shifts [8]. Holmes et al. demonstrated a dose-dependent increase in invasive activity of human ovarian 
cancer SKOV3 cells with exposure to activated platelets, which was decreased with platelet inhibition by prostaglandin E1 [75]. A protective effect against apoptosis from co-culture with platelets was similarly shown in A2780, HeyA8, and SKOV3-ip1 ovarian cancer cell lines, and studies of both human (SKOV3, OVCAR5) and murine (ID8, 2C6) ovarian cancer cell lines have demonstrated direct proliferative effects of platelets on cancer cells mediated through the TGF $\beta$ receptor $[34,76]$. Co-culture of ovarian cancer cells with platelet microparticles or platelets furthermore increases the expression of tumor protein products associated with epithelial-mesenchymal transition [60,77]. Moreover, addition of platelet antagonists to co-cultures decreases ovarian cancer cell invasive activity [77]. These effects have been seen with both inhibitors of the platelet-activating adenosine $5^{\prime}$-diphosphate receptor ( $\left.\mathrm{P}_{2} \mathrm{Y}_{12}\right)$ and aspirin, which inhibits platelet cyclooxygenase to block formation of thromboxane, thereby preventing platelet adhesion and aggregation. Bottsford-Miller et al. leveraged murine models to investigate the therapeutic potential of anti-platelet therapies in ovarian cancer; platelet depletion-with and without chemotherapy - was associated with significant reductions in tumor weight, while platelet transfusion significantly increased tumor weight in orthotopic nude mice. Intriguingly, when transfused platelets were pretreated with aspirin or a direct thromboxane inhibitor, the pro-tumorigenic effects of platelet transfusion were blocked; while some preclinical evidence suggests that aspirin may have intrinsic anti-tumor activity, this specifically only occurred in the presence of platelets, indicating that these results were mediated by effects on platelets [34,78-80]. Inhibition of the $\mathrm{P} 2 \mathrm{Y}_{12}$ platelet receptor has correspondingly been shown to reduce platelet-associated tumor growth in murine models of ovarian cancer [81,82]. In a similar study of the A2780ip2 mouse model, treatment with anti-platelet antibodies resulted in significant reductions of tumor proliferation and microvessel density, as well as substantial tumor necrosis [25].

While platelets activated by VEGF have been shown to participate in extravasation and metastasis of tumor cells, and platelet-derived VEGF in turn promotes angiogenesis by driving further recruitment of endothelial cells, platelets also drive angiogenesis in the ovarian cancer tumor microenvironment [83]. In vitro studies have demonstrated that exposure of ovarian cancer cell lines to activated platelets is associated with a significant increase in VEGF secretion into cellular media [75]. In murine models of ovarian cancer, endothelial markers VEGF and CD31 were found to co-localize with platelets, and co-culture of human ovarian cancer cell lines with platelets increases secretion of several pro-angiogenic factors $[84,85]$. Intriguingly, this preclinical evidence suggests that metformin may abrogate the pro-angiogenic activity of platelets in ovarian cancer [85]. Platelets may also play a role in tumor growth following cessation of anti-angiogenic therapy; withdrawal of anti-VEGF therapies is associated with accelerated tumor growth and concurrent tumor platelet-infiltration, while platelet depletion mitigates these effects in vivo [86]. In addition to promoting tumor angiogenesis and proliferation, formation of tumor-platelet aggregates also serves to shield cancer cells from immune surveillance and shear stress in circulation $[4,87]$.

\subsection{Contributions of Platelets to Ovarian Cancer Progression: Ex Vivo Studies}

Studies of ex vivo human-derived ovarian cancer cells isolated from ascitic fluid have also supported a pro-tumorigenic role of platelets in ovarian cancer. Co-culture of patient-derived ovarian cancer cells with platelets resulted in increased migration and phenotypic changes characteristic of stem-cell-like behavior and epithelial-mesenchymal transition [88]. Further, platelets serve as chemoattractants to tumor cells, suggesting they may act as sites for metastatic seeding, particularly in the peritoneal cavity [88,89]. Ultrastructure variations and increased aggregation in platelets isolated from patients with invasive ovarian cancer may further influence these associations; however, studies evaluating differences in platelet aggregation and activity in ovarian cancer patients have had inconsistent findings [90,91]. Genetic variations in androgen receptor among patients with epithelial ovarian cancer have also been implicated in associations of thrombocytosis with poor survival, as androgens augment platelet activation and activity [92]. 


\subsection{Contributions of Platelets to Ovarian Cancer Progression: Clinical Data}

Studies in the clinical setting have also suggested potential mechanisms underlying the association of thrombocytosis with worse ovarian cancer progression. Among a cohort of 150 patients with newly diagnosed epithelial ovarian cancer, plasma levels of IL- 6 and thrombopoietin corelated with platelet counts and in a smaller cohort, blockage of IL- 6 with the humanized anti-IL-6 antibody siltuximab resulted in sustained and significant reductions of platelet counts [25]. A small clinical trial of siltuximab in patients with platinum-resistant ovarian cancer further demonstrated periods of disease stabilization in approximately $40 \%$ of patients, and significant declines in plasma levels of relevant pro-tumorigenic cytokines including VEGF. However, platelet parameters were not assessed [93]. Recent studies demonstrating associations between expression of Rac1, which is involved in platelet activation and aggregation, epithelial-mesenchymal transition, invasion, vascularity, and ovarian cancer prognosis may provide further mechanistic insights to associations of thrombocytosis with survival [94-96]. This connection is particularly intriguing given the evidence that the R-enantiomer of ketorolac, a widely available drug, exhibits potent inhibition of Rac1 activity and growth of ovarian cancer cells, and peri-operative administration has been associated with a survival benefit in previous retrospective studies of patients with ovarian cancer [97-99]. While use of aspirin has been previously thought to be associated with a reduced risk of ovarian cancer due to inhibition of NF- $\mathrm{KB}$ and inflammatory pathways, epidemiologic data also suggests a role for post-diagnostic use of aspirin and other NSAIDs with anti-platelet activity in decreasing production of thromboxane, a mediator of platelet aggregation, and mitigating disease progression and survival [41-43,100-104].

Associations of thrombocytosis with VTE and pulmonary embolism (PE) have also been suggested to underlie associations with mortality among ovarian cancer patients. Although thrombocytosis is strongly associated with risk of thrombosis in cancer patients, suggesting that platelets play a sizeable role in that process, most but not all studies continue to demonstrate significant associations of elevated platelet count with poor prognosis after statistical adjustment for VTE and/or PE [2,32,55,105].

\section{Conclusions: Incorporation of Platelets into the Clinic and Future Therapeutic Targets}

This review provides strong evidence to support prior claims that thrombocytosis is an independent negative prognostic factor for progression-free and overall survival in epithelial ovarian cancer. A 2019 meta-analysis of 11 studies reported a summary Hazard Ratio (HR) of 1.72 (95\% Confidence Interval (CI): 1.44-2.06) for OS and a summary HR of 1.45 (95\% CI 1.32-1.59) for PFS [44]. Here, we have compiled information from 32 relevant studies ( 24 with only pretreatment and 8 that include platelet measures from after initial treatment) and compared and contrasted methodological details. Although studies using thresholds as low as $>300 \times 10^{9} / \mathrm{L}$ have demonstrated significantly decreased progression-free and overall survival, approximately $50 \%$ used $>400 \times 10^{9} / \mathrm{L}$ as a platelet count threshold to define thrombocytosis. Among 27 studies assessing pretreatment thrombocytosis at the time of primary therapy, $11(41 \%)$ have assessed platelet levels within 14 days of operative diagnosis, while $15(56 \%)$ have assessed platelets from the pretreatment or preoperative periods without further specification. Among 18 studies that have assessed independent associations with OS, DSS, or cancer-specific mortality and pretreatment thrombocytosis, 15 (83\%) demonstrated significant associations with worse survival in multivariable adjusted models. Similarly, among 11 studies that have evaluated PFS or DFS in multivariable adjusted analyses, 10 (91\%) demonstrated significant independent associations with thrombocytosis. Based on the published studies reviewed, we conclude that preoperative thrombocytosis in the setting of first-line treatment has a robust association with worse survival in epithelial ovarian cancer, and thrombocytosis prior to the date of primary surgery (most often within 14 days) is an indicator of increased risk of disease progression and mortality for patients with epithelial ovarian cancer. While future studies should seek to evaluate these questions prospectively, there is now an abundance of evidence demonstrating this association retrospectively across multiple centers.

Evaluating platelet counts throughout treatment and surveillance to monitor response to therapy and progression of disease may have clinical utility. Although only 8 studies to date 
have evaluated associations of post-treatment platelet counts with prognosis, they unanimously found either associations with recurrence, characteristics of aggressive disease, such as chemoresistance, or worse prognosis. Of note, 2 studies described significantly worse prognosis when post-treatment platelet levels decreased by less than $25 \%$ as compared to pretreatment levels. Furthermore, the only published prospective study assessing thrombocytosis and ovarian cancer prognosis suggested that thrombocytosis prior to second-look surgery may also predict disease progression [65]. The utility of thrombocytosis as a biomarker for monitoring disease progression and treatment response should be evaluated in additional clinical settings.

While platelets and tumor cells may synergistically affect each other to drive neoplastic processes, a number of in vitro and ex vivo mechanisms support the role of platelets in mediating tumor survival, proliferation, and chemoresistance; these likely underlie the epidemiologic associations with patient survival. In vivo mouse models have validated these results, demonstrating reductions in tumor growth with anti-platelet therapy, and prospective and retrospective clinical data evaluating direct or indirect anti-platelet agents suggest that anti-platelet therapy may provide a novel therapeutic strategy in ovarian cancer. Clinical trials are underway to evaluate therapies with anti-platelet activity, such as aspirin and metformin, and these will provide further insight into potential therapeutic targets $[40,106,107]$. Available evidence strongly suggests that pretreatment thrombocytosis is an independent prognostic factor for ovarian cancer and that monitoring platelet counts regularly during and after therapy may be a possible avenue to assess response to therapy, disease progression, or recurrence. Future studies should seek to augment our understanding of associations of thrombocytosis with ovarian cancer prognosis to identify potential novel treatment strategies.

Author Contributions: Conceptualization, A.B.-F.; writing —original draft preparation, D.H.H., G.D.C. and A.B.-F.; writing-review and editing, M.A.C., D.H.H. and A.B.-F.; All authors have read and agreed to the published version of the manuscript.

Funding: ABF was supported in part by the Building Interdisciplinary Research Careers in Women's Health (BIRCWH) Program (BIRCWH K12 HD 043483). DHH was supported in part by a 2018 Burroughs Wellcome Fund Physician-Scientist Institutional Award to Vanderbilt University (ID: 1018894).

Acknowledgments: The authors wish to thank Dineo Khabele, Oluche C. Oke, and Fiona Yull for their helpful discussions and contributions to this work, and Spencer Keene and Gwendolyn Holman for their assistance in curating the literature. We also gratefully acknowledge the members and supporters of the Vanderbilt Ovarian Cancer Alliance (VOCAL).

Conflicts of Interest: The authors declare no conflict of interest.

\section{References}

1. Nurden, A. Platelets, inflammation and tissue regeneration. Thromb. Haemost. 2011, 105 (Suppl. 6), S13-S33. [CrossRef] [PubMed]

2. Mammadova-Bach, E.; Mangin, P.; Lanza, F.; Gachet, C. Platelets in cancer: From basic research to therapeutic implications. Hamostaseologie 2015, 35, 325-336. [CrossRef] [PubMed]

3. Menter, D.G.; Tucker, S.C.; Kopetz, S.; Sood, A.K.; Crissman, J.D.; Honn, K.V. Platelets and cancer: A casual or causal relationship: Revisited. Cancer Metastasis Rev. 2014, 33, 231-269. [CrossRef] [PubMed]

4. Schlesinger, M. Role of platelets and platelet receptors in cancer metastasis 06 Biological Sciences 0601 Biochemistry and Cell Biology. J. Hematol. Oncol. 2018, 11, 125. [CrossRef] [PubMed]

5. Evans, T.R.J.; Mansi, J.L.; Bevan, D.H. Trousseau's syndrome in association with ovarian carcinoma. Cancer 1996, 77, 2544-2549. [CrossRef]

6. Cognasse, F.; Laradi, S.; Berthelot, P.; Bourlet, T.; Marotte, H.; Mismetti, P.; Garraud, O.; Hamzeh-Cognasse, H. Platelet Inflammatory Response to Stress. Front. Immunol. 2019, 10, 1478. [CrossRef] [PubMed]

7. Santos-Martínez, M.J.; Medina, C.; Jurasz, P.; Radomski, M.W. Role of metalloproteinases in platelet function. Thromb. Res. 2008, 121, 535-542. [CrossRef] [PubMed]

8. Seizer, P.; May, A.E. Platelets and matrix metalloproteinases. Thromb. Haemost. 2013, 110, 903-909. [CrossRef]

9. Anitua, E.; Andia, I.; Ardanza, B.; Nurden, P.; Nurden, A.T. Autologous platelets as a source of proteins for healing and tissue regeneration. Thromb. Haemost. 2004, 91, 4-15. [CrossRef] 
10. Kim, K.H.; Park, T.Y.; Lee, J.Y.; Lee, S.-M.; Yim, J.-J.; Yoo, C.-G.; Kim, Y.W.; Han, S.K.; Yang, S.-C. Prognostic Significance of Initial Platelet Counts and Fibrinogen Level in Advanced Non-Small Cell Lung Cancer. J. Korean Med. Sci. 2014, 29, 507. [CrossRef]

11. Kim, M.; Chang, H.; Yang, H.C.; Kim, Y.J.; Lee, C.T.; Lee, J.H.; Jheon, S.; Kim, K.; Chung, J.H.; Lee, J.S. Preoperative thrombocytosis is a significant unfavorable prognostic factor for patients with resectable non-small cell lung cancer. World J. Surg. Oncol. 2014, 12, 37. [CrossRef] [PubMed]

12. Taucher, S.; Salat, A.; Gnant, M.; Kwasny, W.; Mlineritsch, B.; Menzel, R.C.; Schmid, M.; Smola, M.G.; Stierer, M.; Tausch, C.; et al. Impact of pretreatment thrombocytosis on survival in primary breast cancer. Thromb. Haemost. 2003, 89, 1098-1106. [PubMed]

13. Stravodimou, A.; Voutsadakis, I.A. Pretreatment Thrombocytosis as a Prognostic Factor in Metastatic Breast Cancer. Int. J. Breast Cancer 2013, 2013, 1-6. [CrossRef]

14. Chadha, A.S.; Kocak-Uzel, E.; Das, P.; Minsky, B.D.; Delclos, M.E.; Mahmood, U.; Guha, S.; Ahmad, M.; Varadhachary, G.R.; Javle, M.; et al. Paraneoplastic thrombocytosis independently predicts poor prognosis in patients with locally advanced pancreatic cancer. Acta Oncol. (Madr.) 2015, 54, 971-978. [CrossRef]

15. Suzuki, K.; Aiura, K.; Kitagou, M.; Hoshimoto, S.; Takahashi, S.; Ueda, M.; Kitajima, M. Platelets counts closely correlate with the disease-free survival interval of pancreatic cancer patients. Hepatogastroenterology 2004, 51, 847-853. [PubMed]

16. Zhao, J.-M.; Wang, Y.-H.; Yao, N.; Wei, K.-K.; Jiang, L.; Hanif, S.; Wang, Z.-X. Poor Prognosis Significance of Pretreatment Thrombocytosis in Patients with Colorectal Cancer: A Meta-Analysis. Asian Pac. J. Cancer Prev. 2016, 17, 4295-4300.

17. Hu, C.Y.; Chen, R.P.; Chen, W.J.; Pang, W.Y.; Xue, X.Y.; Zhu, G.B.; Shen, X. Thrombocytosis is a significant indictor of hypercoagulability, prognosis and recurrence in gastric cancer. Exp. Ther. Med. 2014, 8, 125-132. [CrossRef]

18. Hwang, S.G.; Kim, K.M.; Cheong, J.H.; Kim, H.I.; An, J.Y.; Hyung, W.J.; Noh, S.H. Impact of pretreatment thrombocytosis on blood-borne metastasis and prognosis of gastric cancer. Eur. J. Surg. Oncol. 2012, 38, 562-567. [CrossRef]

19. Lin, R.J.; Afshar-Kharghan, V.; Schafer, A.I. Paraneoplastic thrombocytosis: The secrets of tumor self-promotion. Blood 2014, 124, 184-187. [CrossRef]

20. Eggemann, H.; Ehricke, J.; Ignatov, T.; Fettke, F.; Semczuk, A.; Costa, S.D.; Ignatov, A. Platelet count after chemotherapy is a predictor for outcome for ovarian cancer patients. Cancer Investig. 2015, 33, 193-196. [CrossRef]

21. Torre, L.A.; Trabert, B.; DeSantis, C.E.; Miller, K.D.; Samimi, G.; Runowicz, C.D.; Gaudet, M.M.; Jemal, A.; Siegel, R.L. Ovarian cancer statistics, 2018. CA Cancer J. Clin. 2018, 68, 284-296. [CrossRef]

22. Jayson, G.C.; Kohn, E.C.; Kitchener, H.C.; Ledermann, J.A. Ovarian cancer. Lancet 2014, 384, $1376-1388$. [CrossRef]

23. Kurman, R.J.; Shih, I.M. Pathogenesis of ovarian cancer: Lessons from morphology and molecular biology and their clinical implications. Int. J. Gynecol. Pathol. 2008, 27, 151-160. [CrossRef] [PubMed]

24. Sant, M.; Chirlaque Lopez, M.D.; Agresti, R.; Sánchez Pérez, M.J.; Holleczek, B.; Bielska-Lasota, M.; Dimitrova, N.; Innos, K.; Katalinic, A.; Langseth, H.; et al. Survival of women with cancers of breast and genital organs in Europe 1999-2007: Results of the EUROCARE-5 study. Eur. J. Cancer 2015, 51, 2191-2205. [CrossRef]

25. Stone, R.L.; Nick, A.M.; McNeish, I.A.; Balkwill, F.; Han, H.D.; Bottsford-Miller, J.; Rupaimoole, R.; Armaiz-Pena, G.N.; Pecot, C.V.; Coward, J.; et al. Paraneoplastic thrombocytosis in ovarian cancer. N. Engl. J. Med. 2012, 366, 610-618. [CrossRef]

26. Cozzi, G.D.; Samuel, J.M.; Fromal, J.T.; Keene, S.; Crispens, M.A.; Khabele, D.; Beeghly-Fadiel, A. Thresholds and timing of pre-operative thrombocytosis and ovarian cancer survival: Analysis of laboratory measures from electronic medical records. BMC Cancer 2016, 16, 612. [CrossRef] [PubMed]

27. Digklia, A.; Voutsadakis, I.A. Thrombocytosis as a prognostic marker in stage III and IV serous ovarian cancer. Obstet. Gynecol. Sci. 2014, 57, 457. [CrossRef] [PubMed]

28. Feng, Z.; Wen, H.; Bi, R.; Duan, Y.; Yang, W.; Wu, X. Thrombocytosis and hyperfibrinogenemia are predictive factors of clinical outcomes in high-grade serous ovarian cancer patients. BMC Cancer 2016, 16, 43. [CrossRef] [PubMed] 
29. Allensworth, S.K.; Langstraat, C.L.; Martin, J.R.; Lemens, M.A.; McGree, M.E.; Weaver, A.L.; Dowdy, S.C.; Podratz, K.C.; Bakkum-Gamez, J.N. Evaluating the prognostic significance of preoperative thrombocytosis in epithelial ovarian cancer. Gynecol. Oncol. 2013, 130, 499-504. [CrossRef]

30. Li, A. The prognostic significance of thrombocytosis in epithelial ovarian carcinoma. Gynecol. Oncol. 2004, 92, 211-214. [CrossRef]

31. Ma, X.; Wang, Y.; Sheng, H.; Tian, W.; Qi, Z.; Teng, F.; Xue, F. Prognostic significance of thrombocytosis, platelet parameters and aggregation rates in epithelial ovarian cancer. J. Obstet. Gynaecol. Res. 2014, 40, 178-183. [CrossRef] [PubMed]

32. Man, Y.N.; Wang, Y.N.; Hao, J.; Liu, X.; Liu, C.; Zhu, C.; Wu, X.Z. Pretreatment plasma D-dimer, fibrinogen, and platelet levels significantly impact prognosis in patients with epithelial ovarian cancer independently of venous thromboembolism. Int. J. Gynecol. Cancer 2015, 25, 24-32. [CrossRef] [PubMed]

33. Lee, M.; Kim, S.W.; Nam, E.J.; Yim, G.W.; Kim, S.; Kim, Y.T. The impact of pretreatment thrombocytosis and persistent thrombocytosis after adjuvant chemotherapy in patients with advanced epithelial ovarian cancer. Gynecol. Oncol. 2011, 122, 238-241. [CrossRef] [PubMed]

34. Bottsford-Miller, J.; Choi, H.J.; Dalton, H.J.; Stone, R.L.; Cho, M.S.; Haemmerle, M.; Nick, A.M.; Pradeep, S.; Zand, B.; Previs, R.A.; et al. Differential platelet levels affect response to taxane-based therapy in ovarian cancer. Clin. Cancer Res. 2015, 21, 602-610. [CrossRef]

35. Crasta, J.A.; Premlatha, T.S.; Krishnan, S.M.; Vallikad, E.; Rameshkumar, K. Significance of preoperative thrombocytosis in epithelial ovarian cancer. Indian J. Pathol. Microbiol. 2010, 53, 54-56. [CrossRef]

36. Haddad, L.B.; Laufer, M.R. Thrombocytosis Associated with Malignant Ovarian Lesions within a Pediatric/Adolescent Population. J. Pediatr. Adolesc. Gynecol. 2008, 21, 243-246. [CrossRef]

37. Watrowski, R.; Heinze, G.; Jäger, C.; Forster, J.; Zeillinger, R. Usefulness of the preoperative platelet count in the diagnosis of adnexal tumors. Tumor Biol. 2016, 37, 12079-12087. [CrossRef]

38. Atacag, T. Diagnostic value of thrombocytosis and high CA 125 level in women with adnexal masses. Eur. J. Gynaecol. Oncol. 2012, 33, 517-520.

39. Barber, E.L.; Boggess, J.F.; Van Le, L.; Kim, K.H.; Bae-Jump, V.L.; Brewster, W.R.; Soper, J.T.; Gehrig, P.A. Association of Preoperative Thrombocytosis and Leukocytosis With Postoperative Morbidity and Mortality Among Patients With Ovarian Cancer. Obstet. Gynecol. 2015, 126, 1191-1197. [CrossRef]

40. ClinicalTrials.gov [Internet]. Bethesda (MD): National Library of Medicine (US). 2000 Feb 29. Identifier NCT03378297, IMPACT: A Randomized WOO Study of Novel Therapeutic Agents in Women Triaged to Primary Surgery for EOC. 19 December 2017. Available online: https://clinicaltrials.gov (accessed on 16 September 2020).

41. Merritt, M.A.; Rice, M.S.; Barnard, M.E.; Hankinson, S.E.; Matulonis, U.A.; Poole, E.M.; Tworoger, S.S. Pre-diagnosis and post-diagnosis use of common analgesics and ovarian cancer prognosis (NHS/NHSII): A cohort study. Lancet Oncol. 2018, 19, 1107-1116. [CrossRef]

42. Verdoodt, F.; Dehlendorff, C.; Friis, S.; Kjaer, S.K. Non-aspirin NSAID use and ovarian cancer mortality. Gynecol. Oncol. 2018, 150, 331-337. [CrossRef] [PubMed]

43. Wield, A.M.; Walsh, C.S.; Rimel, B.J.; Cass, I.; Karlan, B.Y.; Li, A.J. Aspirin use correlates with survival in women with clear cell ovarian cancer. Gynecol. Oncol. Rep. 2018, 25, 78-81. [CrossRef] [PubMed]

44. Ye, Q.; Cheng, J.; Ye, M.; Liu, D.; Zhang, Y. Association of pretreatment thrombocytosis with prognosis in ovarian cancer: A systematic review and meta-analysis. J. Gynecol. Oncol. 2019, 30, e5. [CrossRef] [PubMed]

45. Menczer, J. Preoperative elevated platelet count and thrombocytosis in gynecologic malignancies. Arch. Gynecol. Obstet. 2017, 295, 9-15. [CrossRef] [PubMed]

46. Andersen, C.L.; Eskelund, C.W.; Siersma, V.D.; Felding, P.; Lind, B.; Palmblad, J.; Bjerrum, O.W.; Friis, S.; Hasselbalch, H.C.; De Fine Olivarius, N. Is thrombocytosis a valid indicator of advanced stage and high mortality of gynecological cancer? Gynecol. Oncol. 2015, 139, 312-318. [CrossRef] [PubMed]

47. Słabuszewska-Jóźwiak, A.; Dmoch-Gajzlerska, E.; Kozakiewicz, B.; Jakiel, G. The prognostic significance of thrombocytosis in ovarian cancer. Ann. Agric. Environ. Med. 2015, 22, 731-735. [CrossRef]

48. Hu, Q.; Hada, A.; Han, L. Platelet count as a biomarker for monitoring treatment response and disease recurrence in recurrent epithelial ovarian cancer. J. Ovarian Res. 2020, 13, 78. [CrossRef]

49. Menczer, J.; Schejter, E.; Geva, D.; Ginath, S.; Zakut, H. Ovarian carcinoma associated thrombocytosis. Correlation with prognostic factors and with survival. Eur. J. Gynaecol. Oncol. 1998, 19, 82-84. 
50. Zeimet, A.G.; Marth, C.; Müller-Holzner, E.; Daxenbichler, G.; Dapunt, O. Significance of thrombocytosis in patients with epithelial ovarian cancer. Am. J. Obstet. Gynecol. 1994, 170, 549-554. [CrossRef]

51. Qiu, J.; Yu, Y.; Fu, Y.; Ye, F.; Xie, X.; Lu, W. Preoperative plasma fibrinogen, platelet count and prognosis in epithelial ovarian cancer. J. Obstet. Gynaecol. Res. 2012, 38, 651-657. [CrossRef]

52. Nakao, S.; Minaguchi, T.; Itagaki, H.; Hosokawa, Y.; Shikama, A.; Tasaka, N.; Akiyama, A.; Ochi, H.; Matsumoto, K.; Satoh, T. Pretreatment thrombocytosis as an independent predictive factor for chemoresistance and poor survival in epithelial ovarian cancer. J. Ovarian Res. 2020, 13, 55. [CrossRef]

53. Gungor, T.; Kanat-Pektas, M.; Sucak, A.; Mollamahmutoglu, L. The role of thrombocytosis in prognostic evaluation of epithelial ovarian tumors. Arch. Gynecol. Obstet. 2009, 279, 53-56. [CrossRef] [PubMed]

54. Chen, Y.; Zhang, L.; Liu, W.X.; Liu, X.Y. Prognostic significance of preoperative anemia, leukocytosis and thrombocytosis in chinese women with epithelial ovarian cancer. Asian Pac. J. Cancer Prev. 2015, 16, 933-939. [CrossRef]

55. Matsuo, K.; Hasegawa, K.; Yoshino, K.; Murakami, R.; Hisamatsu, T.; Stone, R.L.; Previs, R.A.; Hansen, J.M.; Ikeda, Y.; Miyara, A.; et al. Venous thromboembolism, interleukin-6 and survival outcomes in patients with advanced ovarian clear cell carcinoma. Eur. J. Cancer 2015, 51, 1978-1988. [CrossRef] [PubMed]

56. Chen, J.P.; Huang, Q.D.; Wan, T.; Tu, H.; Gu, H.F.; Cao, J.Y.; Liu, J.H. Combined score of pretreatment platelet count and CA125 level (PLT-CA125) stratified prognosis in patients with FIGO stage IV epithelial ovarian cancer. J. Ovarian Res. 2019, 12, 72. [CrossRef] [PubMed]

57. Okunade, K.S.; Dawodu, O.; Adenekan, M.; Nwogu, C.M.; Awofeso, O.; Ugwu, A.O.; Salako, O.; John-Olabode, S.; Olowoselu, O.F.; Anorlu, R.I. Prognostic impact of pretreatment thrombocytosis in epithelial ovarian cancer. Niger. J. Clin. Pract. 2020, 23, 1141-1147. [CrossRef]

58. Soonthornthum, T.; Suraseraneewong, V.; Kengsakol, K.; Wijaithum, K.; Kasemsan, P.; Prommatt, S. Thrombocytosis in advanced epithelial ovarian cancer. J. Med. Assoc. Thail. 2007, 90, 1495-1500.

59. Komura, N.; Mabuchi, S.; Yokoi, E.; Shimura, K.; Kawano, M.; Matsumoto, Y.; Kimura, T. Pre-treatment prognostic nutritional index is superior to platelet count in predicting disease-specific survival in patients with epithelial ovarian cancer. Int. J. Gynecol. Cancer 2019, 29, 1057-1063. [CrossRef]

60. Tang, M.; Jiang, L.; Lin, Y.; Wu, X.; Wang, K.; He, Q.; Wang, X.; Li, W. Platelet microparticle-mediated transfer of miR-939 to epithelial ovarian cancer cells promotes epithelial to mesenchymal transition. Oncotarget 2017, 8, 97464-97475. [CrossRef]

61. Hefler-Frischmuth, K.; Grimm, C.; Gensthaler, L.; Reiser, E.; Schwameis, R.; Hefler, L.A. Prognostic value of preoperative hyponatremia and thrombocytosis in patients with epithelial ovarian cancer. Wien. Klin. Wochenschr. 2018, 130, 575-580. [CrossRef]

62. Gerestein, C.G.; Eijkemans, M.J.C.; De Jong, D.; Van Der Burg, M.E.L.; Dykgraaf, R.H.M.; Kooi, G.S.; Baalbergen, A.; Burger, C.W.; Ansink, A.C. The prediction of progression-free and overall survival in women with an advanced stage of epithelial ovarian carcinoma. BJOG An Int. J. Obstet. Gynaecol. 2009, 116, 372-380. [CrossRef] [PubMed]

63. Cohen, J.G.; Tran, A.Q.; Rimel, B.J.; Cass, I.; Walsh, C.S.; Karlan, B.Y.; Li, A.J. Thrombocytosis at secondary cytoreduction for recurrent ovarian cancer predicts suboptimal resection and poor survival. Gynecol. Oncol. 2014, 132, 556-559. [CrossRef]

64. Canzler, U.; Lück, H.J.; Neuser, P.; Sehouli, J.; Burges, A.; Harter, P.; Schmalfeldt, B.; Aminossadati, B.; Mahner, S.; Kommoss, S.; et al. Prognostic role of thrombocytosis in recurrent ovarian cancer: A pooled analysis of the AGO Study Group. Arch. Gynecol. Obstet. 2020, 301, 1267-1274. [CrossRef]

65. Bozkurt, N.; Yuce, K.; Basaran, M.; Kose, F.; Ayhan, A. Correlation of platelet count with second-look laparotomy results and disease progression in patients with advanced epithelial ovarian cancer. Obstet. Gynecol. 2004, 103, 82-85. [CrossRef]

66. Gastl, G.; Plante, M.; Finstad, C.L.; Wong, G.Y.; Federici, M.G.; Bander, N.H.; Rubin, S.C. High IL-6 levels in ascitic fluid correlate with reactive thrombocytosis in patients with epithelial ovarian cancer. Br. J. Haematol. 1993, 83, 433-441. [CrossRef]

67. Besbes, S.; Shah, S.; Al-Dybiat, I.; Mirshahi, S.; Helfer, H.; Najah, H.; Fourgeaud, C.; Pocard, M.; Ghedira, I.; Soria, J.; et al. Thrombopoietin Secretion by Human Ovarian Cancer Cells. Int. J. Cell Biol. 2017, 2017, 1873834. [CrossRef] [PubMed] 
68. Guo, R.-X.; Qiao, Y.-H.; Zhou, Y.; Li, L.-X.; Shi, H.-R.; Chen, K.-S. Increased staining for phosphorylated AKT and nuclear factor- $\mathrm{\kappa B}$ p 65 and their relationship with prognosis in epithelial ovarian cancer. Pathol. Int. 2008, 58, 749-756. [CrossRef] [PubMed]

69. Darb-Esfahani, S.; Sinn, B.V.; Weichert, W.; Budczies, J.; Lehmann, A.; Noske, A.; Buckendahl, A.C.; Müller, B.M.; Sehouli, J.; Koensgen, D.; et al. Expression of classical NF-kB pathway effectors in human ovarian carcinoma. Histopathology 2010, 56, 727-739. [CrossRef]

70. Annunziata, C.M.; Stavnes, H.T.; Kleinberg, L.; Berner, A.; Hernandez, L.F.; Birrer, M.J.; Steinberg, S.M.; Davidson, B.; Kohn, E.C. Nuclear factor $\mathrm{\kappa B}$ transcription factors are coexpressed and convey a poor outcome in ovarian cancer. Cancer 2010, 116, 3276-3284. [CrossRef]

71. Kleinberg, L.; Dong, H.P.; Holth, A.; Risberg, B.; Trope', C.G.; Nesland, J.M.; Flørenes, V.A.; Davidson, B. Cleaved caspase-3 and nuclear factor- $\mathrm{kB}$ p65 are prognostic factors in metastatic serous ovarian carcinoma. Hum. Pathol. 2009, 40, 795-806. [CrossRef]

72. Shuang, T.; Wang, M.; Zhou, Y.; Shi, C. Over-expression of nuclear NF-кB1 and c-Rel correlates with chemoresistance and prognosis of serous epithelial ovarian cancer. Exp. Mol. Pathol. 2016, 100, 139-144. [CrossRef] [PubMed]

73. Hufnagel, D.H.; Wilson, A.J.; Saxon, J.; Blackwell, T.S.; Watkins, J.; Khabele, D.; Crispens, M.A.; Yull, F.E.; Beeghly-Fadiel, A. Expression of p52, a non-canonical NF-kappaB transcription factor, is associated with poor ovarian cancer prognosis. Biomark. Res. 2020, 8, 45. [CrossRef] [PubMed]

74. Hutti, J.E.; Pfefferle, A.D.; Russell, S.C.; Sircar, M.; Perou, C.M.; Baldwin, A.S. Oncogenic PI3K mutations lead to NF-kB-dependent cytokine expression following growth factor deprivation. Cancer Res. 2012, 72, 3260-3269. [CrossRef]

75. Holmes, C.E.; Levis, J.E.; Ornstein, D.L. Activated platelets enhance ovarian cancer cell invasion in a cellular model of metastasis. Clin. Exp. Metastasis 2009, 26, 653-661. [CrossRef]

76. Cho, M.S.; Bottsford-Miller, J.; Vasquez, H.G.; Stone, R.; Zand, B.; Kroll, M.H.; Sood, A.K.; Afshar-Kharghan, V. Platelets increase the proliferation of ovarian cancer cells. Blood 2012, 120, 4869-4872. [CrossRef]

77. Cooke, N.M.; Spillane, C.D.; Sheils, O.; O'Leary, J.; Kenny, D. Aspirin and P2Y12 inhibition attenuate platelet-induced ovarian cancer cell invasion. BMC Cancer 2015, 15, 627. [CrossRef]

78. Cho, M.; Kabir, S.M.; Dong, Y.; Lee, E.; Rice, V.M.; Khabele, D.; Son, D.S. Aspirin blocks EGF-stimulated cell viability in a COX-1 dependent manner in ovarian cancer cells. J. Cancer 2013, 4, 671-678. [CrossRef]

79. Selvendiran, K.; Bratasz, A.; Tong, L.; Ignarro, L.J.; Kuppusamy, P. NCX-4016, a nitro-derivative of aspirin, inhibits EGFR and STAT3 signaling and modulates Bcl-2 proteins in cisplatin-resistant human ovarian cancer cells and xenografts. Cell Cycle 2008, 7, 81-88. [CrossRef]

80. Huang, Y.; Lichtenberger, L.M.; Taylor, M.; Bottsford-Miller, J.N.; Haemmerle, M.; Wagner, M.J.; Lyons, Y.; Pradeep, S.; Hu, W.; Previs, R.A.; et al. Antitumor and antiangiogenic effects of aspirin-PC in ovarian cancer. Mol. Cancer Ther. 2016, 15, 2894-2904. [CrossRef]

81. Cho, M.S.; Noh, K.; Haemmerle, M.; Li, D.; Park, H.; Hu, Q.; Hisamatsu, T.; Mitamura, T.; Mak, S.L.C.; Kunapuli, S.; et al. Role of ADP receptors on platelets in the growth of ovarian cancer. Blood 2017, 130, 1235-1242. [CrossRef]

82. Egan, K.; Crowley, D.; Smyth, P.; O’Toole, S.; Spillane, C.; Martin, C.; Gallagher, M.; Canney, A.; Norris, L.; Conlon, N.; et al. Platelet adhesion and degranulation induce pro-survival and pro-angiogenic signalling in ovarian cancer cells. PLoS ONE 2011, 6, e26125. [CrossRef] [PubMed]

83. Möhle, R.; Green, D.; Moore, M.A.S.; Nachman, R.L.; Rafii, S. Constitutive production and thrombin-induced release of vascular endothelial growth factor by human megakaryocytes and platelets. Proc. Natl. Acad. Sci. USA 1997, 94, 663-668. [CrossRef] [PubMed]

84. Yuan, L.; Liu, X. Platelets are associated with xenograft tumor growth and the clinical malignancy of ovarian cancer through an angiogenesis-dependent mechanism. Mol. Med. Rep. 2015, 11, 2449-2458. [CrossRef] [PubMed]

85. Erices, R.; Cubillos, S.; Aravena, R.; Santoro, F.; Marquez, M.; Orellana, R.; Ramírez, C.; González, P.; Fuenzalida, P.; Bravo, M.L.; et al. Diabetic concentrations of metformin inhibit platelet-mediated ovarian cancer cell progression. Oncotarget 2017, 8, 20865-20880. [CrossRef] [PubMed]

86. Haemmerle, M.; Bottsford-Miller, J.; Pradeep, S.; Taylor, M.L.; Choi, H.J.; Hansen, J.M.; Dalton, H.J.; Stone, R.L.; Cho, M.S.; Nick, A.M.; et al. FAK regulates platelet extravasation and tumor growth after antiangiogenic therapy withdrawal. J. Clin. Investig. 2016, 126, 1885-1896. [CrossRef] 
87. Nieswandt, B.; Hafner, M.; Echtenacher, B.; Männel, D.N. Lysis of tumor cells by natural killer cells in mice is impeded by platelets. Cancer Res. 1999, 59, 1295-1300.

88. Orellana, R.; Kato, S.; Erices, R.; Bravo, M.L.; Gonzalez, P.; Oliva, B.; Cubillos, S.; Valdivia, A.; Ibañez, C.; Brañes, J.; et al. Platelets enhance tissue factor protein and metastasis initiating cell markers, and act as chemoattractants increasing the migration of ovarian cancer cells. BMC Cancer 2015, 15, 290. [CrossRef]

89. Gasic, G.J.; Gasic, T.B.; Stewart, C.C. Antimetastatic effects associated with platelet reduction. Proc. Natl. Acad. Sci. USA 1968, 61, 46-52. [CrossRef]

90. Wang, R.; Stone, R.L.; Kaelber, J.T.; Rochat, R.H.; Nick, A.M.; Vijayan, K.V.; Afshar-Kharghan, V.; Schmida, M.F.; Sood, A.K.; Chiu, W. Electron cryotomography reveals ultrastructure alterations in platelets from patients with ovarian cancer. Proc. Natl. Acad. Sci. USA 2015, 112, 14266-14271. [CrossRef]

91. Feng, S.; Kroll, M.H.; Nick, A.M.; Sood, A.K.; Afshar-Kharghan, V. Platelets are not hyperreactive in patients with ovarian cancer. Platelets 2016, 27, 716-718. [CrossRef]

92. Li, A.J.; Karlan, B.Y. Androgen mediation of thrombocytosis in epithelial ovarian cancer biology. Clin. Cancer Res. 2005, 11, 8015-8018. [CrossRef]

93. Coward, J.; Kulbe, H.; Chakravarty, P.; Leader, D.; Vassileva, V.; Leinster, D.A.; Thompson, R.; Schioppa, T.; Nemeth, J.; Vermeulen, J.; et al. Interleukin-6 as a therapeutic target in human ovarian cancer. Clin. Cancer Res. 2011, 17, 6083-6096. [CrossRef] [PubMed]

94. Aslan, J.E.; Tormoen, G.W.; Loren, C.P.; Pang, J.; McCarty, O.J.T. S6K1 and mTOR regulate Rac1-driven platelet activation and aggregation. Blood 2011, 118, 3129-3136. [CrossRef]

95. Fang, D.; Chen, H.; Zhu, J.Y.; Wang, W.; Teng, Y.; Ding, H.F.; Jing, Q.; Su, S.B.; Huang, S. Epithelial-mesenchymal transition of ovarian cancer cells is sustained by Rac1 through simultaneous activation of MEK1/2 and Src signaling pathways. Oncogene 2017, 36, 1546-1558. [CrossRef]

96. Gonzalez-Villasana, V.; Fuentes-Mattei, E.; Ivan, C.; Dalton, H.J.; Rodriguez-Aguayo, C.; Fernandez-De Thomas, R.J.; Aslan, B.; Monroig, P.D.C.; Velazquez-Torres, G.; Previs, R.A.; et al. Rac1/Pak1/p38/MMP-2 axis regulates angiogenesis in ovarian cancer. Clin. Cancer Res. 2015, 21, 2127-2137. [CrossRef]

97. Guo, Y.; Kenney, S.R.; Muller, C.Y.; Adams, S.; Rutledge, T.; Romero, E.; Murray-Krezan, C.; Prekeris, R.; Sklar, L.A.; Hudson, L.G.; et al. R-ketorolac targets Cdc42 and Rac1 and alters ovarian cancer cell behaviors critical for invasion and metastasis. Mol. Cancer Ther. 2015, 14, 2215-2227. [CrossRef]

98. Hudson, L.G.; Gillette, J.M.; Kang, H.; Rivera, M.R.; Wandinger-Ness, A. Ovarian tumor microenvironment signaling: Convergence on the Rac1 GTPase. Cancers (Basel) 2018, 10, 358. [CrossRef] [PubMed]

99. Hudson, L.G.; Cook, L.S.; Grimes, M.M.; Muller, C.Y.; Adams, S.F.; Wandinger-ness, A. Dual actions of ketorolac in metastatic ovarian cancer. Cancers (Basel) 2019, 11, 1049. [CrossRef]

100. Brasky, T.M.; Liu, J.; White, E.; Peters, U.; Potter, J.D.; Walter, R.B.; Baik, C.S.; Lane, D.S.; Manson, J.E.; Vitolins, M.Z.; et al. Non-steroidal anti-inflammatory drugs and cancer risk in women: Results from the Women's Health Initiative. Int. J. Cancer 2014, 135, 1869-1883. [CrossRef] [PubMed]

101. Trabert, B.; Ness, R.B.; Lo-Ciganic, W.H.; Murphy, M.A.; Goode, E.L.; Poole, E.M.; Brinton, L.A.; Webb, P.M.; Nagle, C.M.; Jordan, S.J.; et al. Aspirin, nonaspirin nonsteroidal anti-inflammatory drug, and acetaminophen use and risk of invasive epithelial ovarian cancer: A pooled analysis in the ovarian cancer association consortium. J. Natl. Cancer Inst. 2014, 106, djt431. [CrossRef]

102. Trabert, B.; Poole, E.M.; White, E.; Visvanathan, K.; Adami, H.O.; Anderson, G.L.; Brasky, T.M.; Brinton, L.A.; Fortner, R.T.; Gaudet, M.; et al. Analgesic use and ovarian cancer risk: An analysis in the Ovarian Cancer Cohort Consortium. J. Natl. Cancer Inst. 2019, 111, 137-145. [CrossRef] [PubMed]

103. Ylikorkala, O.; Kauppila, A.; Viinikka, L. Prostacyclin and thromboxane in ovarian cancer: Effect of cytostatics and prostaglandin synthesis inhibitors. Gynecol. Oncol. 1983, 16, 340-345. [CrossRef]

104. Altinoz, M.A.; Korkmaz, R. NF-kB, macrophage migration inhibitory factor and cyclooxygenase-inhibitions as likely mechanisms behind the acetaminophen- and NSAID-prevention of the ovarian cancer. Neoplasma 2004, 51, 239-247.

105. Mulder, F.I.; Candeloro, M.; Kamphuisen, P.W.; Di Nisio, M.; Bossuyt, P.M.; Guman, N.; Smit, K.; Buller, H.R.; Van Es, N. The khorana score for prediction of venous thromboembolism in cancer patients: A systematic review and meta-analysis. Haematologica 2019, 104, 1277-1287. [CrossRef] [PubMed] 
106. ClinicalTrials.gov [Internet]. Bethesda (MD): National Library of Medicine (US). 29 Feb 2000. Identifier NCT02122185, Metformin and Chemotherapy in Treating Patients With Stage III-IV Ovarian, Fallopian Tube, or Primary Peritoneal Cancer. 24 April 2014. Available online: https:/clinicaltrials.gov/ct2/show/ NCT02122185?term=NCT02122185\&draw=2\&rank=1 (accessed on 16 September 2020).

107. ClinicalTrials.gov [Internet]. Bethesda (MD): National Library of Medicine (US). 2000 Feb 29. Identifier NCT02437812, Study of Paclitaxel, Carboplatin and Oral Metformin in the Treatment of Advanced Stage Ovarian Carcinoma. 8 May 2015. Available online: https:/clinicaltrials.gov/ct2/show/NCT02437812?term= NCT02437812\&draw $=2 \&$ rank $=1$ (accessed on 16 September 2020).

Publisher's Note: MDPI stays neutral with regard to jurisdictional claims in published maps and institutional affiliations.

(C) 2020 by the authors. Licensee MDPI, Basel, Switzerland. This article is an open access article distributed under the terms and conditions of the Creative Commons Attribution (CC BY) license (http://creativecommons.org/licenses/by/4.0/). 